\title{
Resistance in Postcolonial Literature with Reference to Sahar Khalifeh's Wild Thorns
}

\author{
Said Ahmed Aboudaif Mahmoud \\ Faculty of Arts, Assuit University, Egypt \\ saidaboudaif@yahoo.com
}

$\begin{array}{ll}\begin{array}{l}\text { Received: } \\ \text { 13/07/2019 }\end{array} & \text { Abstract } \\ & \text { This study presents a theoretical and practical framework of resistance as } \\ \text { accepted: } & \text { as present of postcolonial criticism. It describes different types of resistance } \\ 21 / 08 / 2019 & \text { is adapted to trace 'resistance Literature' throughout the postcolonial } \\ & \text { criticism. The main aim here is to highlight the theme of resistance against } \\ \text { Keywords: } & \text { the colonial structure from the point of view of a Palestinian novelist. The } \\ \text { Resistance Literature, } & \text { application of the analytic descriptive approach intends to analyze the } \\ \text { Palestine Literature, } & \text { theme of resistance at this colonial period from different points of view. } \\ \text { Wild thorns, } & \text { The theme of resistance is tackled from a sociological and cultural point of } \\ \text { Sahar Khalifeh } & \text { view. The ideology of both the colonized and the colonizer is revealed } \\ & \text { throughout this critical analysis. }\end{array}$

\section{INTRODUCTION}

This study provides a theoretical and practical framework of resistance as a concept of postcolonial criticism. It describes different types of resistance as presented in Khalifeh's (2000) novel Wild Thorns. The research examines the historical nature of the Israel-Palestine struggle which is inherited from the British Colonial period. A historical approach is adapted to trace 'resistance Literature' throughout the postcolonial criticism. The main aim here is to highlight the theme of resistance against the Israeli colonial structure from the point of view of a Palestinian novelist. The study intends to analyze what resistance means from the points of view of the Palestinian people and the Israelis. The literary critical analysis deals with the literary work from the point of view of the author, the characters and the readers to illustrate the goal of the novelist. Freud (2009) and others consider the literary work as a mirror which reflects the inner motives of the author. Thus, analyzing a literary text exposes the motives of the author and how they are reflected on his characters as well as received by his readers. The critical analysis of the fictional characters can help both ways to illuminate the author's motives and the readers' expectations. The analysis of the characters in Khalifeh's (2000) Wild Thorns aims at exploring how the characters are delineated concerning the theme of resistance from a sociological, political and cultural point of view. The ideology of both the colonized and the colonizer will be revealed throughout this critical analysis. The main objective of this study is to present a critical reading of Khalifeh's (2000) Wild Thorns to reveal the concept of resistance from different sociological points of view. Different types of resistance and its ideological and political background in a postcolonial novel Wild Thorns are examined. 


\section{THEORETICAL FRAMEWORK}

Harlow (1987) in her book Resistance Literature offers new potentials of literary criticism to discuss different types of resistance. In the preface of her book, she explains "like the resistance and national liberation movements which it reflects and in which it can be said to participate, not only demands recognition of its independent status and existence as literary production, but also explains a challenge to the codes and canons of both the theory and practice of literature and its criticism as these have developed in the West" (Harlow, 1991, p. 2). She presents and identifies what is now known as 'Palestinian Literature' as well as she explains the definition of the term 'resistance' from the point of view of different writers which she has discussed in her book. She said that the term 'resistance' was first applied in a description of Palestinian literature in 1966 by the Palestinian writer and critic Ghassan Kanafani in his study Literature of Resistance in Occupied Palestine: 1948-1968 (cited in Harlow, 1991, p. 2).

Moreover, Said (1978) discussed the same idea of resistance. He wrote about the lost identity of the Arabs because of the long periods of Western Colonization. Critics and writers like Said urged Arabian poets and novelists to write about the problem of colonization and to search about the lost identity of the Arabs. Darweesh (1941), a Palestinian writer and poet, writes about the resistance of the Palestinian people against their colonizer. Darweesh introduces his country as in exile. Shatz (2001) stated that it is a metaphor for the loss of Eden. In addition, one of the most important resistance writers of the 'Palestinian Literature' is Kanafani (2013) who wrote about the struggle of the Palestinians under the occupation. In his short stories, he describes the feelings of the children in the refugee camps and he explains his political views and beliefs about liberation and resistance. According to O'Neil (2004), he is as one of the greatest world writers of the twentieth century.

Fanon (2003), a postcolonial theorist, wrote about violent resistance. Fanon is a West Indian Psychoanalyst known for his theory that some neuroses are socially generated and he is known for his writings about the national liberation of colonial peoples. Young (2001) in his book about colonization speaks about Fanon's physical violent resistance. He says that Fanon believes that such involvement of the mind helps the colonized to use their inner psychological powers against the colonizer. Fanon states that it is "turning the inculcation of inferiority into self-empowerment" (Young, p. 275).

The connection between post colonialism and Resistance Literature is obvious as both of them speak about the colonizer and the colonized. Peter and Patrick (2014) present a firsthand definition of post-colonial as a term that "it refers to a period coming after the end of colonialism" (p. 1). The question that arises here is what colonialism are we talking about? Is it only the colonialism of the British and the French empires? What about other forms of colonialism of the recent age? Peter and Patrick add "post-colonialism may then refer in part to the period after colonialism, but the question arise, after whose colonialism?" (p. 1). The fact that post colonialism theory talks about the ideological and the political differences and how every part is defending his own argument makes it clear that there is a connection between resistance and post colonialism. Moore-Gilbert, Bart, Gareth, and Maley (2014) confirm this point of view "Postcolonial critics often have a stake in post colonialism as a political process in the 


\section{Resistance in Postcolonial Literature with reference to Sahar Khalifeh's Wild Thorns}

context of specific national struggle. One thinks here of Fanon and Algeria, and Said and Palestine" (p. 4).

Fanon (1965) explains his view of resistance against the colonizer in his book The Wretched of the Earth. He argues "National liberation, national reawakening, restoration of the nation to the people or Commonwealth, whatever the name used, whatever the latest expression, decolonization is always a violent event" (p. 1). Thus, Fanon believes in the violent resistance against the colonizer to accomplish decolonization. He adds that colonized people have no other choice but to meet colonists' physical and emotional acts of violence with a same violence, until "the last become first" (p. 10). The idea here is that Postcolonialism does not only mean the colonizer and the colonized but also the victims of this relationship and the victims' rights to resist in different forms. Young (2003) clarifies the fact of recent colonialism and the problems created by such aggressive forms of imperialism. He talks about the refugees' problem, "if you are unlucky- like the Somali refugees in Kenya, the Palestinian refugees in Gaza, Jordan, Lebanon, Syria, the West Bank, or the 'internally displaced persons in Sri Lanka or the south African of the 1970s - you may find that you are to be there for a decade, or for several." (p. 10).

Since we have come to the idea of how to describe resistance against the colonizer and the possibility of having what so called a resistance theory, what about the types of resistance. Do the colonialized people have the right of resistance and to what extent it is considered an act of defense? Parry (1994) argues "that the colonised were never successfully pacified is well known to the postcolonial study of colonialism and the long and discontinuous process of decolonization. But proposals on how resistance is to be theorized display fault-lines with the discussion" (p. 172).

Fanon (2003) believes that fighting the colonized is not only physical or materialistic but also mental and emotional. He thinks that this kind of hatred from the colonized to the colonizer is emotional and psychological which creates some kind of inner resistance. This psychological inner resistance creates self-consciousness which is represented in forms of cultural awareness against the colonizer. Kebede (2001) writes about Fanon that "He sees violence as a necessary therapy for a cultural disease brought about by colonial subjugation. The mere departure of the colonizer is not enough; liberation and dignity cannot be recovered unless the colonized get involved in violent performances" (p. 539). Thus, Fanon thinks that violent resistance is a solution to decolonization but the fact remains that there are different forms of non-violent resistance. The self-consciousness and the cultural awareness are nonviolent resistance that can accomplish great results against colonialism. Literature is an important agent as a form of non-violent resistance which can stimulate and send messages of resistance against the colonizers. However, violent resistance is manifested in literature through the behavior of the characters and their motives. The characters in a literary work are influence by the social factors and the political opinions around them. The violent action of the character is examined according to the threats and the oppression situations which he faces and the oppression situations are created because of the colonizer-colonized relationship. Within the mind of the character, the oppression is created because of his lost identity in his homeland. Thus, he (the character) feels that he has a duty to protect his identity against the act of colonization. Thus, violent resistance becomes a solution to such characters. Hence, this study 
examines Palestinian postcolonial literature and the concept of resistance as an important theme in Palestinian literature.

\section{LITERATURE REVIEW}

One of the good studies about resistance literature related to Palestinian struggle against the occupation is the article The Writing on the Walls: The Graffiti of the Intifada by Peteet (1996). The article explores graffiti as a form of cultural production during a sustained political contest. It shows the struggle of Palestinians to resist the occupation in a peaceful and cultural form. Another great study published at the Muse Project about narrative Palestinian writers and narrative writings is A Study Between Complicity and Subversion: Body Politics in Palestinian National Narrative by Amireh (2003). The study provides some narratives to "exemplify the inextricable interconnection between gender and nationalism in the Palestinian context: The first is an intifada legend, which, with slight variations, told of a stone-throwing incident that purportedly took place in a West Bank town in 1988 at the height of the first intifada/uprising" (p. 747). The second narrative text provided by the writer is about a newspaper report about a kind of gum that contains hormones and given to Palestinians. "It was about a kind of chewing gum that allegedly was being marketed by the Israelis in the territories of the Palestinian National Authority. According to the Palestinian Ministry of Supply, this was no ordinary gum; it was a "sexual gum" containing hormones" (p. 747).

Moreover, an article of JSTOR Journal with the title, Gender and the Palestinian Narrative of Return in Two Novels of Kanafani by Zalman (2003) is another important study about Palestinian novelists. The article introduces two novels about the idea of return to Palestine. The author explains that the article "argues that the gender is intrinsic to the narratives established in theses novels, and that in them new forms of masculinity are constructed in relation to national loss and national restoration. Finally, the study about Palestinian's resistance in literature and arts is presented by Hamdi (2011) through his article entitled Bearing Witness in Palestinian Resistance Literature. In this article the author examines some Palestinian writers and how they used the theme of resistance in their works. In his abstract the writer explains that:

This article examines how artists of resistance, such as Naji Al Ali, Mahmoud Darwish and Ghassan Kanafani, use the concept of bearing witness to tragedy as a tool of resistance and to guard against the idea of liberation itself dying. It is argued that the state of Israel has used assassination as a means of extinguishing the will of the Palestinian people to resist (p. 1).

\section{THE NOVELIST SAHAR KHALIFEH}

Sahar Khalifeh is a Palestinian feminist writer. She is a contemporary novelist who is concerned with the issues of women liberation and the Palestinian women causes. She wrote six novels about the Israeli-Palestinian struggle and the modern Palestinian history. She wrote her two novels, Al-Subbar (Arabic word for the cactus) (1976) and Abbad al-Shams (Arabic word for the sunflower) (1980) about Palestinians' resistance against the occupier. Throughout these novels, the writer explains the dilemma of the Palestinians and their bitter choice of either remaining in their homeland under occupation and being forced to work in factories and places of their occupier, or leaving homeland to live in the outside as fugitives away from their families and their childhood memories. Khalifeh (2000) in her novel Wild Thorns, discusses 


\section{Resistance in Postcolonial Literature with reference to Sahar Khalifeh's Wild Thorns}

the theme of alienation and identity through her characters to reveal the real problem of the struggle and to come to conclusion about the real essence of resistance.

Historically, after the British withdraw from Palestine in 1948, the Arabs were defeated in 1967 from Israel. It occupied the Palestinians homeland and expands sanctions on them. The Palestinian women writers explain the oppression and the disposition that is forced on the people in the occupied land. Shahina (2016) states:

Taking a discursive route to the fraught territory of Palestine will tell us the stories of tortures that the writers have to face from the oppressive regime, due to the selfrepresentations through their works. The road blocks and checkpoints in the Palestinian territory in a way symbolically suggest the blocks and checkpoints that which the author has to undergo in their process of self-definitions and the emergence into a writer (p. 17).

Khalifeh's Palestinian protagonists are searching for their identities in a post-colonial period. Most of her novels are placed in a historical context related to the Israeli occupation of Palestine. In an interview with Nazareth (1980), Khalifeh says:

When you say "the liberation of women" you cannot liberate the woman without liberating the man. So both of them should be liberated in order to have the liberated woman. This is the way also with nations. You cannot liberate the Arabs without liberating the Israelis ...You cannot liberate one part and ignore the other if you want the final solution (p. 82).

\section{AL-SUBBAR -WILD THORNS' OVERVIEW}

The novel takes place in Nablus in 1972. It tells about Usama who travels for five years from Palestine his homeland and returns to find out that a huge change had occurred in the Palestinian community under occupation. Usama's family is divided between their desire to resist the colonizer and the needs of their daily survival. Usama is on a mission to blow buses of workers who work in a factory in Tel Aviv. He discovers that his cousin Adil works in the same factory. Nuwar, his sister, is in love with a Palestinian fighter who is in the Israeli prison. Another character, Zuhdi works in the factory and he kills one of his Israeli coworkers. Usama and Zuhdi are killed by Israeli soldiers and they destroy their houses. Khalifeh illustrates a fictional story about violent and non-violent resistances against the colonizer. Kahf (2000) explains:

Khalifeh's work examines the genesis of violence in the crucible of occupation.

How does an idealistic young man turn into a person willing to blow up a busload

of Israel-bound Arab workers for the cause of Palestinian liberation, even when

those workers include members of his own family and community? (p. 451).

This novel depicts Palestinian social life under the Israeli occupation.

\section{THE NOVEL AS A POSTCOLONIAL LITERATURE}

To understand this novel of a Middle East background, a historical survey must be highlighted to place this novel in its historical setting. A discussion of a post-colonial resistance must take into consideration the historical importance of this part of the world. Cooper (2005) 
indicates that "a historical practice sensitive to the different ways people frame the relationship of past, present, and future through an understanding of the situations and conjunctions that enable and disable particular representations" (p. 149). The Israeli-Palestine struggle is an ongoing problem for over ninety years. The Palestinian Nakba (Arabic for catastrophe) of 1948 resulted in the establishment of the state of Israel and the loss of the Palestinian land. Palestinians lost their towns and villages which are renamed with Israeli names and they are forced to exile. Ten million are in exile and Four million live in Gaza strips, West Bank and in Israel (Gaza Strip and West Bank, 2019). Ideas of disposition and fugitives became an important theme of most Palestine and Arab writers. The first Palestinian Intifada (Arabic for uprising) lasted for six years from 1987 to 1993 and the second Intifada lasted from 2000 to 2005. Smith (2010) sees that the second Intifada is riddled with suicide bombings and sectarian violence. According to Smith, the second Intifada featured intense Palestinians-Israeli violence that killed over 6,500 Palestinian and Israelis combined. The West Bank is occupied by Israel and is described as a society under occupation that is why its people are in a state of war.

\section{WILD THORNS AS A RESISTANCE LITERATURE}

The novel Wild Thorns is a representation of Palestinian resistance literature and as a contemporary Arabic literature in English translation. The novel is a good example of the Israel-Palestine struggle and digs deep into the Palestinian identity, searching for political, social and religious reasons for resistance in a post-colonial environment. It talks about Palestine as 'the promised land' which is an ironic gesture to both the Palestinians and the Israelis. For the Israelis, Palestine is the Promised Land and they have the right of return (a law enacted by Israel 1950 that gives Jews rights to immigrate and settle in Israel). Palestinians who have immigrated because of the occupation and are forced to work in Gulf countries also have to return back to their promised land. The novel stresses the fact that the right of return is denied for the Palestinians. This exposes one of the main themes of postcolonial literature which is the disposition of the protagonists and their search for lost identities.

The novel searches for solutions of identification problems and problems of displacement of the self in the homeland. It explains how the formation of identity is lost because of political and social reasons related to the power of colonial period. This is clearly expressed when Usama faces the Israeli soldier at the check point on the border. It is his first time to experience the occupation because he has left for many years. Usama is interrogated by the Israeli soldiers and he is asked the same questions in a ridicules way. Usama uses the Arabic names of the Palestinian towns and the border guard keeps using the Hebrew names of the towns. "My mother moved to Nablus," Usama states. "Why did your mother move to Shekem?" the guard replies. "She likes Nablus," Usama retorts. "Why does she like Shekem?" the guard answers" (Khalifeh, 2000, p. 13). This dialogue reveals the occupation ways to change the history and to eradicate the identity of the Palestinians. It also reveals Usama's persistence on confirming his identity. The occupation wants to change the Palestinian culture to be able to defeat people like Usama and Adil. This is a typical postcolonial situation. In addition, Usama thinks of the change happened to his people under occupation, "What had happened to these people? Was this what the occupation had done to them? Where was there will to resist, their steadfastness? His disgust erupted into angry question: 'where's the resistance then?" (Khalifeh, 2000, p. 21). 


\section{$\underline{\text { Resistance in Postcolonial Literature with reference to Sahar Khalifeh's Wild Thorns }}$}

Writers of the colonial period do not have the power to face their colonizers in real life that is why they use their fictional powers to express their resistance. Palestinian writers are good examples of writing about resistance to overcome their colonizers. The analysis of Wild Thorns reveals the process of Israel colonization and how does this affect the two main protagonists in understanding their identities. The protagonists in the novel are displaced and both of them have different experiences about displacement according to social and political factors related to colonial reasons of Israeli occupation. This doesn't mean that the writer intends to tell the readers that they are two different personalities. On the contrary, the writer presents those two protagonists as one personality with two different views. This reveals the idea of the unity between the 'self and the shadow' (Adil and Usama). The unity between Usama's decisions to violent resistance equals the wisdom and rationality of Adil who thinks that the right thing is to insure survival of his family to defeat the colonizer intensions.

Khalifeh (2000) provides different types of characters to symbolize the social and the political situation in the occupied territories. She presents the lives of the Palestinians as workers, prisoners or freedom fighters. Basil is a resistant character who appeals to Usama and gives him hope while Zuhdi is presented as a wise, reasonable character. He accepts to work in an Israeli factory and accepts their rules. He believes that accepting the occupation is his way out but he is triggered to violent resistance. Usama is a Palestinian political activist who is educated in Egypt and worked in the Gulf. He became an active member outside Palestine for many years without a real connection with the people in the inside. He led some attacks against Israel. Othman (2017) clarifies the radical change in the personality of Usama:

One of the Palestinian icons in Khalifa's Assabbar is Usama Al-Karmi, the protagonist. Upon his return to Palestine after a long time of training in Jordan, Usama feels he has become "a single shot in a fusillade ... a rocket, a guided missile" (6)....[this] emphasizes the strength of Palestinian resistance and warns the Israelis that its icons will act as guided missiles; that is, sacrifice their lives to fight the Israeli occupation (p. 15)

Adil is Usama's cousin who represents the Palestinians in the inside. He has a big family and an Israeli job. He believes that resistance does not mean violence. The writer discuses a main question in her novel about the life of the Palestinians in the occupied territory and how do they survive? Usama expresses his chock from the change which has happened in the Palestinian social life in dealing with the occupation and accepting the colonizer. He sees the taxi driver smoking Israeli cigarettes and tells him that he eats Israeli rice. "Abu Muhammed nodded in agreement. 'Yes, he said. "I smoke El Al now.' 'Israeli cigarettes?' Usama asked, scandalized. "And I eat Israeli rice, Israeli tahini and Israeli sugar" (Khalifeh, 2000, p. 21). The novel exposes different situations of the Palestinians who want to live in peace and accept the facts of the occupation. Usama lost contacts with the Palestinians in the inside and he questioned their ability to resist the occupier. He thinks that his people has given up resistance and accepted the occupation. Usama did not think of the people's need to live in peace and survive under military occupation.

Throughout the novel there is an interior dialogue about the difference between the two main protagonists Usama and Adil. The dialogue is between idealism and pragmatism. Usama 
is the idealist who returned from the Gulf to perform violent resistance against the colonizer. Adil is the pragmatic character who believes that the responsibility of supporting the family is his choice of resistance. This means to him that the occupation must be dealt with. The question that might be asked is about those two protagonists. Can we consider them as two opposites of the same person? Is it like two faces of the same coin? Can we think of Adil as only a pragmatic who is accepting the colonizer? Can we think of Usama as only a violent resistant against the colonizer? Hughes (2011) explained the difficulty of considering the two protagonists as opposites, "As shown through the characters of Usama and Adil, theoretical binaries become incapable of providing readers with the tools they need to understand and navigate the complicated literary landscape that Wild Thorns provides" (p. 13).

Khalifeh means to explore the division within the Palestinian community concerning the idea of resistance. When Usama was searching for Adil at home, he met Basil, Nuwar's younger brother, who introduced him to some of his Palestinian friends discussing the education policy of the occupier. The discussion about Israel education policy to force the Palestinians to leave the country and immigrate to the Gulf makes Usama feel some hope that those young people understand the reasons for resistance of the occupier. First, at elementary school, we're repressed and tamed. Then at secondary school, our personalities are crushed. In high school they foist an obsolete curriculum on us and our families begin pressuring us to get the highest grades so we can become doctors and engineers. Once we've actually become doctors and engineers, they demand that we pay them back for the cost of our studies. And our parents don't work their fingers to the bone to pay for our education so that we'll return and work for peanuts at home. So the only solution is emigration, which means working in Saudi Arabia, Libya, and the Gulf. What's the result of all this? Educated people leave the country, and only workers and peasants remain. And that's exactly what Israel wants to happen. (Khalifeh, 2000, p. 59)

\section{TYPES OF RESISTANCE}

Khalifeh (2000) introduces two different types of colonial resistance. The first one is the violent resistance represented by Usama who believes that the only way to cause change is through violence against the colonizer. The second type of resistance is the non-violent resistance represented by Adil who believes that Palestinian people have the right to live peacefully in their land which means that they have to accept the reality of colonization. The novelist portrays the two characters as if living in two different worlds. This explains why Usama is chocked to see the changes happen to his people while he was away. He did not accept that Palestinians completely depend on the Israeli economy for jobs and for food. His refusal is manifested in his accusation of the Palestinians who are not taking the violent road as traitors and collaborators. Usama refuses that the bread seller sells bread made in Israel; the seller says "Look friend, we're not the first to work with them. While we were still wandering the streets of Nablus looking for bread to eat, your kind were running around Tel Aviv looking for companies to award you franchises so you could sell their products" (Khalifeh, 2000, p. 68). The novelist provides an outstanding portray of the protagonist Adil, and she tries to convince the reader of Adil's points of view about his idea of non-violent resistance. Adil is willing to work in Israel as a laborer to support his family which he considers a resistance. His opposite is Usama, who thinks that the revolution and fighting the enemy is everything. It is the only type of resistance regardless the emotional side of considering the 


\section{Resistance in Postcolonial Literature with reference to Sahar Khalifeh's Wild Thorns}

people and their lives. This is clear when Usama declares that he is willing to blow up the buses of Israel's laborers even if his cousin Adil is in the bus. He thinks that he can accept this kind of sacrifice. Metres (2010) writes about this character:

Sahar Khalifeh's novel Wild Thorns compellingly dramatizes the struggle within Palestinian society, within families, and within individual characters, to articulate and participate in a meaningful and productive resistance to occupation. Telling the story of a West Bank Palestinian, Usama, who has returned after five years to engage in violent resistance against the occupation, Khalifeh shows how Usama must confront how life under occupation is different than he imagined, but not the simple defeat and humiliation that he views it (p. 86).

When comparing the two protagonists, a big difference is intended by the writer. Usama is characterized as a tragic hero whose resistance is figured as a sacrifice to be a martyr. Bernard (2010) explained the tragic sense in the character of Usama saying:

He uncritically glorifies a generic notion of armed resistance and scorns his fellow countrymen for their compliance with the Israeli regime, though he has no real knowledge of the conditions of their lives under occupation. In Usama's final moments, he thinks of his mother and of the land of Palestine, in a tragic pastiche of the rhetoric of heroic sacrifice (P. 352).

Usama talks to his mother "There's no escape from death. You, mother, you're an angel. And me, I'm a real lion, mother; tell everyone I died a martyr, a martyr to the cause. A martyr to the land. I love you, mother. The oven fire. The smell of burning dung. The flute. Scarves. Wedding celebrations. The bride. Nuwar. Salih. Weddings. Yet to come" (Khalifeh, 2000, p. 185). Usama is not only a tragic hero searching for sacrifice for his country to defend it against the colonizer, but he is also a romantic dreamer who wants to change the whole world. He wants to create a free world full of love and beauty. Usama is a poet and he writes poetry about love but because of his belief and love of his country he has changed. This romantic sense in the character of Usama is important in two ways. First it humanizes this fictional character. Second, it proves the writer's declaration that the novel reflects a personal experience. This is the intention of the author who tries to create real life situations to make her protagonists look like real life people. The author explains the inner struggle within the personality of Usama who fights with himself against the idea of being romantic and peaceful. His role in life is to be a fighter not to be a dreamer. He has to accomplish his mission through violent resistance. He cannot accept the fact that he has feelings inside him as a romantic lover. This is a concept intended by the writer to signify the death of romanticism at the character of Usama and other Palestinians who have the same concept of violent resistance. The idea of Usama's humanism is clear in the novel. Both the author and the reader are concerned with this humanistic description. This is a kind of humanistic psychology which is interested in the individual's behavior and his inner force to accomplish self-identification. Cherry (2015) states that:

Humanistic psychology was instead focused on each individual's potential and stressed the importance of growth and self-actualization. The fundamental belief of 
humanistic psychology is that people are innately good and that mental and social problems result from deviations from this natural tendency (p. 1).

The author argues that those terrorists and killers (from the concept of the occupier) are human beings defending their country and freedom. Usama is seen all the time weeping over his love of the land which shows his gentle and romantic feelings. It is clear that Usama has chosen the path of violent resistance to defend himself against the occupier who occupied his motherland and killing his family.

He watched the play of light on the veins of his hand. Amazement. Confusion. He was sensitive and confused, like many other men. He touched the earth he loved. Yes, but. The time for poetry and dreams of passion was past. And this hand. This very hand! Those two other hands that had covered the shocked face of a little blond girl (Khalifeh, 2000, p. 162).

Usama is a male Arab figure which means in a Middle East background, a defender or a protector who must bear the responsibility of defending the family and the land. The typical muscular figure in a Middle East background has an important role in creating attraction to the character of Usama. Adil also has a muscular role of keeping the family because it is his duty and responsibility to take care of the family. What about the female figure in this analysis? The author has different points of view about the female figure. Mainly it is the land of Palestine. Usama is doing his duty of defending his mother (Palestine) the great symbol of love of his life.

\section{TYPICAL PROTAGONISTS}

Khalifeh (2000) portrays the two characters (Usama and Adil) as dreamers who fail to fulfill their freedom or attain happiness. While Usama is trying to remember his past days in Palestine, he reveals his dreams, his lost idealization and romanticism.

This constant longing for the unknown, this feeling of melancholy that overwhelms me whenever I hear a song or smell a flower, and the sense of elation I feel at sunset. My love and yearning for the very earth of this green land of mine, so blessed and so filled with goodness. A romantic, right? No way! (Khalifeh, 2000, p. 9).

This magnificent parallelism of the two characters (Usama and Adil) has to be recognized within the theory of the Swiss psychologist Carl Jung that as known as the Jungian archetypes. Both of them are carrying images and symbols from the past in their unconsciousness. Both of them have feelings of shame because of their failure to accomplish their aims. The two characters complete each other as if they are meant to be one character. While Adil who lives under occupation losses his potentials to resist, Usama still has his will to resist and even to commit violent resistance to achieve his aims.

Adil is a dreamer too who wants to accomplish moderation between the desires of his family and the realities of the occupation. Adil's family is fighting the occupation in different ways. His young brother Basil stones the Israeli soldiers and his sister Nuwar secretly in love with a revolutionary. His father hates the occupation and he does not have fears when his son 


\section{Resistance in Postcolonial Literature with reference to Sahar Khalifeh's Wild Thorns}

is arrested by the Israeli soldiers. The situation of Basil clearly explains the attitude of the whole family regarding the occupation.

Two soldiers grabbed Basil, who offered little resistance. ...while his sister Nuwar stared dumb-founded from a window. 'Whatever God wills, so be it,' his father could be heard shouting. 'But what came over the boy? Does he think he can free Palestine all by himself?' The boy's mother burst into tears (Khalifeh, 2000, p. 162).

The writer is making an important argument about the theme of religion in this conflict from the point of views of different characters. The unification of the two protagonists is viewed differently from the religious point of view of both Usama's mother and his cousin Nuwar. Those two women are satisfied with Adil's reaction against occupation and his views of resistance, while they have different believes about Usama's ideas. His mother believes that "Good will settle everything" (Khalifeh, 2000, p. 32). While Usama's cousin believes "We'll settle it all ourselves" (Khalifeh, 2000, p. 34).

Adil is represented as trapped in a middle situation which means that he does not like the occupier but he accepts the reality of occupation and gets benefits of it. Even though, he has an advantage that he has good relations with the people and the community where he lives. Usama does not have this advantage because he does not have connection with his people and family. The 'revolution' is everything to him, to the point that if his cousin, Adil, is in the buses that Usama blows up, Usama thinks he can accept the loss. Can one think of Adil as a non-violent resistant? Some critics think that Adil is a passive resistant because he is taking care of his family and keeping them inside Israel at the time that the colonizer wants to drive them away. In fact, Adil's situation is different from other characters who not only accept the occupation but they also lost their faith in resistance. Prestwood (2003) clarifies:

Because such characters see the land as no longer belonging to them and their people, but to foreign oppressors, they see no need to defend it and risk their lives for the benefit of the Israelis. Like the cab driver that Usama encounters when he first returns to Palestine, the guard and his son have given up any hope of reclaiming the land, and have chosen to benefit themselves, even by taking Israeli jobs (p.60).

The two protagonists (Usama and Adil) are created by the author as two extremes in their relation to the colonizer (Violent and non-violent) to explain the division in the Palestinian community. Eventually, the two examples are having the same end which means that both of them are results of the terrible occupation and the situations created by the colonization.

\section{A HUMANIST VISION}

The novelist emphasizes the idea of humanism through the characters of Adil and Usama. Adil is portrayed more human than Usama. He is the miserable who is torn from inside between his resistance desires to fight for his country and the family obligations which is clearly described to convey to the reader the psychological suffering of this passive resistant. "He bears everyone's burdens, Adil does. Yes, he carries the troubles of all. He's got nine people hanging around his neck, not to mention the kidney machine. Poor Adil" (Khalifeh, 2000, p. 31). The situation that happened in the bar between Usama and Adil explains that Adil is a fighter who is concerned more with the people and their problems more 
than his concern with the occupier. In the bar Usama accuses Adil of escaping the reality of occupation but Adil proves that he understands the occupier and his discrimination between the Palestinians and the Israelis. Adil tells Usama about his Palestinian co-worker (Zuhdi) who lost his hand while working in the factory and the owners refused to call him an ambulance. He tells him about the differences between the Palestinian workers and the Israelis. "Here there's a big difference between Muhammad and Cohen: Muhammad gets the heavy work, Cohen the light. The Jewish workers have cafeterias with tables and chairs, but we sit on the ground to eat, in the sun or in the garage with the scrap metal and the oil and grease" (Khalifeh, 2000, p. 76).

The character of Zuhdi is an interesting humanistic one. Zuhdi's fear that he will be out of work because of his accident is explained. He says that his wife will come back to beg people for food just like before he works for the Israelis. This character is introduced in a very humanistic vision to support the point of view of the writer about her character Adil. Zuhudi is a passive resistant fighter. "How long are we going to put up with this lousy situation? I've had it up here; up to here, I tell you. We can't please our own people, or those bastards over there either. I swear by God Almighty, if it weren't for my kids I'd take off for Syria and come back with a machine gun" (Khalifeh, 2000, p. 75). The biggest confrontation between the two fighters in the novel appears when Usama tells Adil about his plan to blow up the buses of Palestinian workers. Usama has made up his mind that this is his way of violent resistance to fight the occupier and Adil rejects this way of killing your own people for an ultimate goal which is to force the occupation out of country. 'Listen. There are orders to blow the buses taking the workers into Israel... 'Your conscience!' Adil jeered. 'Your conscience! What about those who get killed or injured? Abou Sabir, for example. Who'll feed their children and clothe their wives? ... 'They do that even when their fathers are alive, 'retorted Usama, 'so what good their fathers anyway? they're making a pretty poor job of bringing up the new generation, distorting the glories of resistance' (Khalifeh, 2000, pp. 64$65)$.

\section{CONCLUSION}

In short, the critical analysis of Wild Thorns reveals the real intention of the author to expose the situation of the Israeli occupation to Palestine. She wants to be in a middle position like her protagonist Adil. She denounces violent resistance and clarifies non-violent resistance against the Israeli occupier. She declares that the real reasons of these political and social problems are created because of the occupation. In addition, the analysis of her protagonists reveals the bewilderment of resistance choice and the broken feelings they have got. The author presents her characters in very humanistic situations to convince the readers of their right cause. The novel Wild Thorns does not present absolute answers about who is right and who is wrong. It presents real life situations of the Palestinian people under occupation. It reveals the secrets of violent resistance from the point of view of the Palestinians. Moreover, it sheds light on the violence from the occupier side against the people under occupation. Khalifeh succeeded in portraying the characters of Usama and Adil in completely two different ways to support her idea about the existence of two the types of resistance. She focused on the humanistic vision of her characters to be able to go inside them to show their real feelings. Thus, the study is provided with different concepts of resistance as a postcolonial criticism. Since resistance literature is related to the Palestinian community, Wild 


\section{$\underline{\text { Resistance in Postcolonial Literature with reference to Sahar Khalifeh's Wild Thorns }}$}

Thorns is a novel about the Palestinian struggle under the Israeli occupation. The author of the novel introduces different types of characters to explain real life situations of Palestinians under occupation. In general, Wild Thorns is a typical novel of post colonialism related to resistance literature.

\section{Bibliography}

Amireh, A. (2003). Between complicity and subversion: Body politics in Palestinian national narrative. The South Atlantic Quarterly, 102(4), 747-772.

Bernard, A. (2010). Another black September? Palestinian writing after 9/11. Journal of Postcolonial Writing 46(3-4), 349-358.

Chales Harrison and Paul Wood. (1993). On dreams. In excerpts. Art in theory 1900-1990. Cambridge: Blackwell Pub.

Cherry, K. (2015, November 26). Humanistic psychology: The third force in psychology. Retrieved from: http://psychology.about.com/od/historyofpsychology/a/hist_humanistic.htm

Cooper, F. (2005). Colonialism in question theory, knowledge, history. Berkeley: University of California Press.

Fanon, F. (1965). The Wretched of the Earth Vol. 149. New York: Grove Press.

Fanon, F. (2003, November 12). West Indian psychoanalyst and philosopher. Retrieved from: http://www.britannica.com/biography/Frantz-Fanon

Freud, S. (2009). On creativity and the unconscious: The psychology of art, literature, love, and religion. Haper: Collins.

Gaza Strip and West Bank. (2019, Augest 9). Retrieved from: https://prayercast.com/gaza-strip-andwest-bank.html

Hamdi, T. (2011). Bearing witness in Palestinian resistance literature. SAGE Journals, 52(3), 21-42.

Harlow, B. (1987). Resistance literature. New York: Methuen.

Harlow, B. (1991). Sites of struggle. Studies in Chicano literature, culture, and ideology criticism in the Borderlands, 149-64.

Hughes, M. A. (2011). Representations of identity in three modern Arabic novels. Colonial Academic Alliance Undergraduate Research Journal 29(1), 5-13.

Jung, C. G. (2005). Modern man in search of a soul. New York: Routledge.

Kahf, M. (2000 no.2). Wild Thorns (book Review). World literature today 74, p. 451.

Kanafānī, G. (2013). ‘Ālam laysa la-nā. Cyprus: Rimal Publications.

Kebede, M. (2001). The rehabilitation of violence and the violence of rehabilitation: Fanon and Colonialism. Journal of Black Studies, 539-562.

Khalifeh, S. (2000). Wild thorns. Northampton: Interlink Publishing Group .

Metres, P. (2010). Vexing resistance, complicating occupation: A contrapuntal reading of Sahar Khalifeh's wild thorns and David Grossman's the smile of the lamb. College Literature 37(1), 81109. 
Moore-Gilbert, Bart, Gareth, and Maley. (2014). Postcolonial criticism. London: Routledge.

Nazareth, P. (1980). An interview with Sahar Khalifeh. The Iowa Review, pp. 67-86.

O'Neil, P. (2004). Great world writers: Twentieth century. Vol.1. London: Marshall Cavendish.

Othman, A. (2017). Foreignization \& domestication strategies of metaphor translation in Sahar Khalifa's assabbar: a cognitive, reader oriented approach. European Journal Of English Language and Literature Studies 5(6), 12-21.

Ovies Mohamdi and Zeinab Sedeghi. (2014). Double colonisation of Palestine in Sahar Khalifeh's wild thorns. International Journal of Women's Research 3(1), 65-77.

Parry, B. (1994). Resistance theory-Theorrising resistance, or two cheers for nativism. Colonial discourse/postcolonial Theory, 172-196.

Peteet, J. (1996). The writing on the walls: The graffiti of the Intifada. JSTOR, 11(2), 139-159.

Peter C., and Patrick W. (2014). An introduction to post-colonial theory. Routledge: Prentice hall/Harvester Wheatsheaf.

Prestwood, E. B. (2003). Paradise lost, and lost again: Limitations and realities of Palestinian identity in exile, occupied Palestine and Israel. M A Thesis. North Carolina, North Carolina State, USA.

Shahina, M. A. (2016). Authoring vs authority: censorship, trauma and fugitivity in the post dispossession Palestinian women writers. Singularities, 113-117.

Said, E. (1978). Orientalism. New York : Vintage 1994.

Shatz, A. (2001, December 21). A poet's Palestine as a metaphor. Retrieved from: http://www.nytimes.com/2001/12/22/books/a-poet-s-palestine-as-a-metaphor.html

Smith, C. D. (2010). "A History with documents." In Palestine and the Arab-Israeli conflict. 4th ed. Bedford/St.: Martin's.

Webb, A. (2009). Literature from the modern Middle East: making a living connection. The English Journal 98(3), 80-88.

Yasir Suleiman and Ibrahim Muhawi. (2006). Literature and nation in the Middle East: An overview. Edinburgh: Edinburgh University Press.

Young, R. (2001). Postcolonialism: A historical introduction. Oxford: B.Blackwell.

Young, R. (2003). Postcolonialism . Oxford: Oxford University Press .

Zalman, A. (2003). Gender and the Palestinian narrative of return in two novels by Ghassan Kanafani. JSTOR Journal, 10-11(1-2), 17-43. 